\title{
The Reshaping of Mexican Labor Exports under NAFTA: Paradoxes and Challenges
}

\author{
Raúl Delgado-Wise \\ Autonomous University of Zacatecas \\ Humberto Márquez Covarrubias \\ Autonomous University of Zacatecas
}

From the perspective of the political economy of development, this article analyzes the role played by Mexican labor in the U.S. productive restructuring process under the aegis of the North American Free Trade Agreement. By conceptualizing the labor export-led model it dissects three basic mechanisms of regional economic integration: maquiladoras, disguised maquilas, and labor migration. Not only does this analytical framework cast light on the contributions made by Mexican migrants to the economies of the United States and Mexico, it also reveals two paradoxes: the broadening of the socioeconomic asymmetries between the two countries, and increased socioeconomic dependence on remittances in Mexico.

\section{INTRODUCTION}

As a result of the ongoing integration of the Mexican economy with that of the United States, fueled by the North American Free Trade Agreement (NAFTA), Mexico has become the leading exporter in Latin America and the thirteenth-largest in the world. At first sight, this fact would appear to confirm the country's entry into the so-called First World, as was promised by the proponents of neoliberal reform. Nevertheless, Mexico is also the world's leading exporter of migrant workers, almost all of whom head for the United States, which is associated with the expansion of the asymmetries between the two countries and the exacerbation of phenomena such as employment insecurity, poverty, and social marginalization - a condition we refer to as precarization. ${ }^{1}$ What is the explanation for this paradox of regional economic integration supposedly based on the neoclassical principle of convergence arising from "free trade"?

\footnotetext{
${ }^{1}$ Precarization is a concept utilized here to describe an increasing change of previously guaranteed permanent employment conditions into mainly worse-paid, uncertain jobs.
} 
The aim of this article is to offer a theoretical and practical response to that question. To achieve that, it analyzes the role assigned to Mexican labor in the U.S. productive restructuring process, which began in the 1980s and remains ongoing today. In order to transcend the dominant view of migration studies based on methodological nationalism, ethnocentrism, and the problems of migrant assimilation into the destination society, and to critically reclaim the contributions of leading-edge approaches such as transnationalism and the empirical evidence produced by disciplinary studies, chiefly at the micro- and mesosocial levels, there is a vital need for studies that contextualize the migration phenomenon from a macro viewpoint, examining the strategic structures and practices that explain the dynamics and inequalities inherent in contemporary capitalist development. This perspective is provided by the political economy of development.

In the case at hand, this approach contributes to the analysis of regional economic integration and the role played in that context by labor migration. Thus, the key analytical dimensions to be considered are:

1. Geostrategics: the geoeconomic and geopolitical shape adopted by regional economic integration.

2. Transnational labor market: the role of the Mexican workforce in productive restructuring.

3. Development model: the implications of neoliberal policies in Mexico.

4. Social subjects: the participation of migrant and nonmigrant social sectors in the regional integration dynamic.

Our argument posits that the current process of economic integration based on NAFTA is organized around what we have called the labor export-led model (Delgado-Wise and Cypher, 2005; Delgado-Wise and Márquez, 2005), implemented by means of the interplay of three complementary mechanisms: (1) the maquiladora industry, (2) the disguised maquila, and (3) labor migration.

On the basis of those broad premises, the paper is divided into five sections. The first offers a description of the analytical model, focusing on the two first axes of the process whereby Mexican labor is exported: maquila and disguised maquila. The second sets out the main effects of maquilization on the Mexican economy: in other words, it describes the structural dynamics associated with labor exports. Section three deals with the quantitative and qualitative aspects of the recent upswing in the migration phenomenon under the aegis of NAFTA and it explores the role assigned to Mexican immigrants within the U.S. economy. The fourth section describes the contradictory 
dynamic arising between economic integration and international migration in terms of the deepening of the asymmetries that exist between the two countries and the exacerbation of the migration phenomenon. Finally, as a general conclusion, section five sets out some of the main socioeconomic implications for both the United States and Mexico arising from the model based on exports of Mexican labor.

\section{CHEAP LABOR: THE ENGINE OF MEXICAN EXPORTS}

Echoing the optimistic proclamations of neoliberal globalization, Mexico is generally considered by international agencies and its own government as a successful example of regional economic integration because of the expansion of its foreign trade, particularly in the manufacturing sector. Note that Mexico is the world's eighth-biggest trading country and the largest in Latin America. It alone accounts for $44 \%$ of Latin America's exports and $49 \%$ of its imports. At first sight, as indicated in Figure I, it is apparent that between 1998 and 2005 Mexican exports increased almost sevenfold, rising from US $\$ 30.7$ billion to $\$ 213.7$ billion. Clearly, the 1994 launch of NAFTA marked an inflection in the upward trend.

It also indicates that manufacturing is the principal component of Mexican exports: in 2005 they accounted for $81.6 \%$ of the total (Banco de México, 2006). Added to this is the fact that the export profile has attained a high level of high-technology component contents, comparable to that of the United States. According to figures from the World Bank (2005), the high-technology component rate of exports was, for Mexico, $21 \%$ and, for the United States, $31 \%$. All these figures are used to back up claims of the alleged evolution of Mexico's export platform toward what has been called the secondary-exporting model. ${ }^{2}$

The optimistic view of Mexico's economic integration with the United States recalls the notion of open regionalism put forward by the Economic Commission for Latin America and the Caribbean (ECLAC) and the InterAmerican Development Bank (IDB) (ECLAC, 1994; Baumann et al., 2002), understood as

a process of growing economic interdependence at the regional level, fueled both by preferential integration agreements [such as NAFTA] and by other liberalization and

${ }^{2}$ This model is conceived as a step forward in the evolution of the import-substitution development model, in which manufacturing exports became the dynamic factor of national economic growth. 


\section{Figure I. Mexico: Exports Growth}

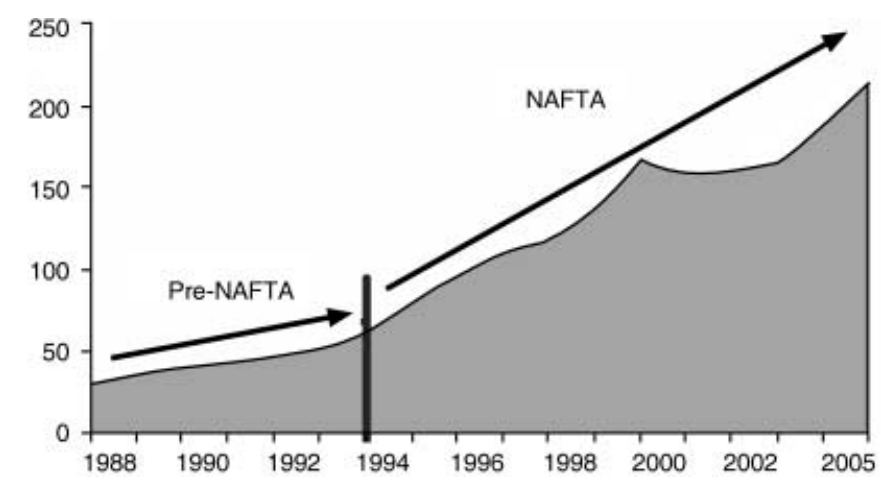

Source: Bank of Mexico.

deregulation policies, in order to increase the competitiveness of the region's countries and to consolidate, to the extent that is possible, the foundations for a more open and transparent international economy. (ECLAC, 1994:8)

Set out in that way, however, that notion is merely a distorted view of Mexican national development insofar as national development is confused with the development of elite segments of foreign and national capital.

To understand the process of regional integration under way between the Mexican and U.S. economies, it is essential to clarify just what the country actually exports and to deflate the myth that Mexico has a buoyant export manufacturing sector. In order to tackle this task, we offer a new theoretical approach to the Mexican economy, the touchstone of which is the concept of the labor export-led model, ${ }^{3}$ understood as the restructuring of the Mexican economy to orient it toward the exterior in response to a strategy of U.S. capital to secure for itself cheap labor for use at various levels of the productive restructuring process in the binational arena. We use this analytical category to explain the complex strategy of exporting labor - mostly underqualified, politically and economically unregulated, and insecure flexible labor - based on three closely related mechanisms: (i) maquiladoras, (ii) disguised maquilas, and (iii) labor migration.

The maquiladora industry began operations in Mexico during the 1960s, at the end of the Bracero Program, which had sent thousands of seasonal

${ }^{3}$ It should be noted that in addition to manpower (the country's leading export, with a net contribution to the balance of trade of US $\$ 20$ billion in 2005), Mexico exports natural resources (chiefly crude oil) and assets (which, for the most part, come from the privatization of stateowned companies). 
agricultural workers to the United States to cover the labor shortage caused by World War II. Following the end of the war, the U.S. adopted an industrialization strategy that involved the establishment of industrial plants in areas with abundant cheap labor (Russel, 2006). These plants follow the maquila model in that they are assembly facilities tied in with internationalized productive processes and practically no integration with the domestic economy. Thus, they import most of the components they use and sell most of their output abroad (Dussel, 2003; Dussel, Galindo, and Loría, 2003). Since they are also based on precarized labor, it is clear that their dynamizing impact on the domestic economy tends to be restricted to the meager wages they pay out.

In order to understand the maquila, it is necessary to keep in mind its place as part of an international production system. The location of assembly plants abroad complements the manufacturing industry - in this case, that of the U.S. - by integrating productive chains that globalize design, production, and marketing, without the head offices losing control (Gereff, 2001). The relocation of operations to plants located in countries such as Mexico is because they offer fiscal incentives, government supports, and, essentially, workers who are cheap and docile. In other words, maquila differs from traditional export processes in that, from its origin, it obeys a strategy orchestrated by U.S. companies such as General Electric, RCA, Zenith, and General Motors to lower production costs by employing cheap labor in assembly plants located chiefly in the northern regions of Mexico. Its operating mechanics also involve the movement of tax-exempt components, machinery, equipment, technology, designs, and organizational schemes from the U.S. parent companies.

An analysis of Mexico's new export profile reveals the high levels of dynamism and specific weight attained by maquiladoras, the exports of which increased 28-fold between 1982 and 2005, when they accounted for more than half (US\$96.756 billion) of all manufactured exports (US\$174.521 billion). Furthermore, the added value of maquila production represents an ever diminishing contribution to the output of that same sector; while in 1990 it accounted for $20 \%$, by 2003 it had fallen to $8 \%$. Nevertheless, between 1995 and 2005, employment in maquiladoras rose from 648,300 to 1.16 million.

There is another important sector within Mexico's manufactured exports which, although it operates with a similar logic to that of maquila, is not officially classified as such. This sector, which accounts for slightly more than $30 \%$ of manufactured exports, is classified as disguised maquila in consideration of the following characteristics (Delgado-Wise and Cypher, 2005): 
Figure II. Mexico: Manufactured Exports by Type

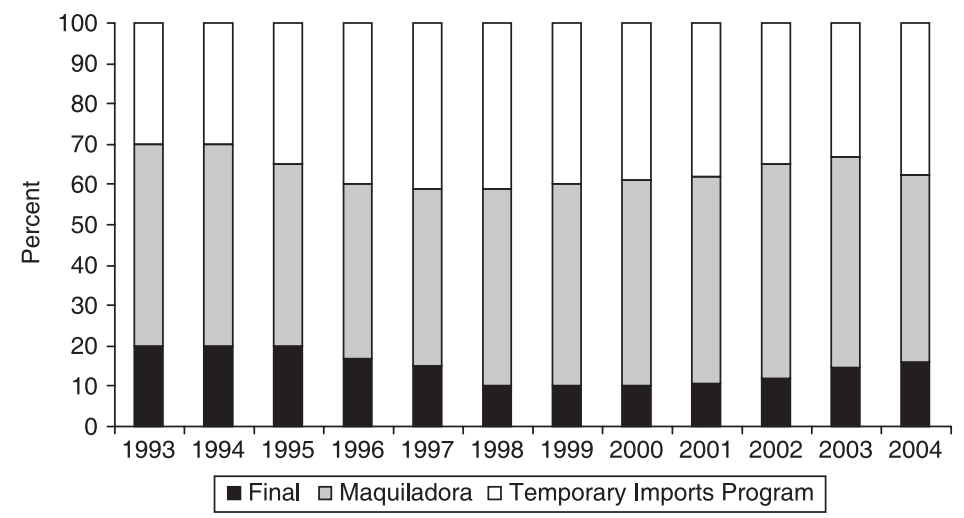

Source: Banco Nacional de Comercio Exterior, Atlas de Comercio Exterior, Mexico.

1. Like maquiladoras, disguised maquilas benefit from the subsidies and tax breaks offered by the government's temporary imports program. They operate under the same mechanisms of tax benefits in trade. The economic importance of this import regime - maquila plus disguised maquila - is such that it explains $84.6 \%$ of Mexico's exports in 2004 (see Figure II).

2. Unlike the maquila sector, its productive system has greater technological intensity and complexity. The prototypical cases are the automobile and electronics industries, generally under the leadership of large multinational U.S. companies.

3. In operating terms, the maquila and disguised maquila are connected through intrafirm trade and outsourcing subcontracting methods. The trading relations arising from this model account for between $65 \%$ and $75 \%$ of the total (Durán and Ventura-Dias, 2003).

4. The disguised maquila employs at least 500,000 workers (Capdevielle, 2005). In contrast to those of the maquiladora sector, these workers have slightly more specialized skills, and earn at least 50\% more. However, those in the disguised maquila work under conditions of increasing employment insecurity, diminishing wages, and required higher productivity.

On the basis of the above considerations, in determining the content of Mexican exports it is essential to identify what the country actually exports 
through maquila and disguised maquila. Due to the high imported component levels of both activities, ranging from $80 \%$ to $90 \%$ of the export value, the benefits for Mexico are basically restricted to the wage earnings - in other words, the value of the labor incorporated into the exports. This means that what is occurring is the indirect exportation of labor or, alternatively, the exportation of the workforce without requiring the Mexican workers to leave the country (Tello, 1996). This is a crucial conceptual element that demystifies the purported orientation of Mexican exports toward manufactured goods and that reveals regressive movement in the export platform. If indirect exports of labor are added to the direct exportation of the workforce through labor migration, the true content of Mexico's exports is revealed. This is the basis for our characterization of the current model of export growth as the cheap labor export-led model.

In connection with this, it should be noted that the ratio of wage differences between Mexico and the United States is generally around 1:7 in disguised maquila, rising to almost twice that figure in direct maquila. For 2003, the International Labour Organization (ILO) has detected a ratio of 1:11 between the earnings of Mexican manufacturing workers in general (direct maquila, disguised maquila, and other industrial sectors) and workers in the same sector in the United States (Howard, 2005). Under NAFTA, wages in the disguised maquila sector have fallen by more than $12 \%$, whereas in the maquiladora sector, and in spite of rising productivity, they have risen by around 3\%, representing an increase in wages of barely 30 US $\$$ in 2005.

The maquila-based production model, which implies the indirect exporting of labor, does not generate shared profits and, in addition, the prices of its exports are artificially set by the companies themselves, without declaring any profits. Using that maneuvering, net profits are transferred abroad while, at the same time, the jobs created are subsidized by the Mexican economy. As can be seen, in practice the Mexican export model represents a contradiction in the idea of freely interplaying market forces preached by neoliberal orthodoxy and, worse, it leads to the ransacking of resources that would otherwise serve to dynamize the Mexican economy.

The structural fragility of the export dynamics of the Mexican economy is invariably subject to variations in the U.S. economy and, most particularly, to changes in the static and short-term comparative advantage of relying on cheap labor. Even though the maquiladoras consolidated their position at the center of Mexico's export model in the 1990s, in terms of the growth observed in employment and output, a certain decrease has been experienced since the 
end of 2000 on account of falling demand in the U.S. and competition from countries with lower wages than Mexico - such as China and the Central American nations - which caused the relocation of maquiladoras and consequent relative growth in wage levels in maquiladoras installed in Mexico (De la Garza, 2004). Mexico has recently suffered major decreases in the expansion of its manufactured exports on account of factors such as reduced dynamism within the U.S. economy and the entry of China into the World Trade Organization (WTO) in December 2001 (Huerta, 2004).

\section{DISMANTLING OF THE MEXICAN ECONOMY BYTHE EXPORT $D Y N A M I C$}

Beginning in the 1980s, and with greater intensity since the enactment of NAFTA, Mexico adopted a hardline macroeconomic policy aimed at favoring, almost exclusively, the growth of the export sector. Trade liberalization encourages the expansion of exports, but by failing to generate productive chains within the Mexican economy, it tends to inhibit the rhythm of growth. Moreover, export growth is supported by an even higher rate of growth in imports, which translates into a negative impact on the balance of payments and on economic dynamics in general. Mexico has been running a trade deficit since the onset of NAFTA: in 2005, for example, it totaled US\$7.558 billion. Between 1994 and 2005, GDP grew at no more than an annual average of $2.9 \%$, while exports expanded by $12.4 \%$ and imports by $13.4 \%$.

One of the immediate effects of indiscriminate trade liberalization and the macroeconomic policies of "structural adjustment" and "economic stability" has been the deterioration of production and structural unemployment and underemployment. The Mexican productive apparatus is deindustrializing progressively and the value of Mexican labor is being left as the sole component that generates added value, in that at present, $77 \%$ of the inputs of the productive process are imported. In this process at least 40 productive chains have been dismantled, including small- and medium-sized Mexican enterprises that supplied large-scale exporters and the domestic market alike (Cadena, 2005).

As a result of low rates of growth, the dismantling of the productive apparatus, and the regime whereby profits are sent abroad under neoliberal policies and NAFTA, Mexico is characterized by, inter alia, a low growth rate and structural inability to create sufficient formal jobs to improve the standards of living of workers and their families. According to Dussel (2005), between 1991 and 2004 formal employment, defined as those workers registered with 
the Mexican Social Security Institute (IMSS), recorded annual increases of barely 489,000 jobs. However, those figures account for only $30.19 \%$ of the corresponding increase in the economically active population (EAP), which clearly indicates the severity of the problem of unemployment and underemployment affecting Mexican society.

To compound this, the inadequate number of jobs created are characterized by labor precarization. In other words, maquilas, disguised maquilas, and the other productive sectors are based on the employment of cheap labor, low or nonexistent levels of unionization, high worker turnover, and a lack of job security. All of these are associated with increased subcontracting and, worse, with the relocation of productive units to other countries and regions with lower wages. Given those circumstances, it has been estimated that $69.2 \%$ of the Mexican manpower was forced to seek employment in the so-called informal sector or directly in the U.S. economy.

The inadequate creation of formal jobs is followed by (i) a notable drop of $15.6 \%$ in manufacturing wages between 1980 and 2004, in contrast to the sector's increased productivity, (ii) the informal sector accounting for almost $50 \%$ of the jobs created in Mexico between 1988 and 2003, and (iii) an increase from 12.9 to 15.9 million in the number of poor households over the same period (Delgado-Wise and Cypher, 2005). Consequently, the veil of supposed progress in export manufacturing conceals the contraction of a significant part of the Mexican economy, which is reduced and compelled to serve as a labor reserve for foreign capital, principally from the USA, thus paving the way for the growth and expansion of labor migration.

\section{DIRECT LABOR EXPORTS: THE BASIS OF THE MEXICO-UNITED STATES MIGRATION SYSTEM}

It is common knowledge that the Mexico-United States Migratory System is one of the oldest, most complex, and most dynamic in the world. Although factors such as its historic roots, the massive volumes involved, and the closeness of the two countries (Durand and Massey, 2003) define its shape, there can be no doubt that the backbone of the migratory flow is its labor-oriented nature - in other words, it entails the direct exportation of labor. Its history can be traced back to the Treaty of Guadalupe-Hidalgo (1848), when approximately half the territory of Mexico passed into the hands of the U.S. and many Mexicans became de facto immigrants solely due to the movement of the country's borders. From that point on, and most particularly since the end of the 19th century, the characteristics and conceptions of the phenomenon, 
TABLE 1

Main Labor Export Countries

\begin{tabular}{lcc}
\hline \hline Country & $\begin{array}{c}\text { Net Annual Migration } \\
\text { (thousands) }\end{array}$ & $\begin{array}{c}\text { Net Migration Rate } \\
\text { (per 1,000 inhabitants) }\end{array}$ \\
\hline Mexico & -400 & -3.9 \\
China & -390 & -0.3 \\
India & -280 & -0.3 \\
Indonesia & -200 & -0.9 \\
Philippines & -180 & -2.3 \\
\hline
\end{tabular}

Source: United Nations Population Division (2006).

and the policies applied to it, underwent significant changes in line with far-reaching transformations that took place within the economic dynamics of each country and forms of integration existing between the two nations. ${ }^{4}$

In its current phase, Mexican migration is characterized by an unprecedented level of dynamism, particularly since the launch of NAFTA. Note, in this connection, that over the 34 years from 1970 to 2004, the number of Mexican-born residents of the U.S. increased 13-fold (Conapo, 2004). This has made Mexico the world's number one exporter of migrants. According to recent estimates from the United Nations Population Division (2006), between 2000 and 2005 a net annual average of 400,000 Mexicans left the country to set up residence in the United States. In second place comes China $(390,000)$, followed by India with 280,000 (see Table 1). At the same time, the United States has the highest levels of immigration in the world (absorbing $20 \%$ of the total) and, in that country, Mexican immigrants represent the largest contingent (27.6\%) (Conapo, 2004).

The dimensions attained by the migration phenomenon are also eloquent: in 2004 the population of Mexican-origin residents in the United States was estimated at 26.6 million, including immigrants - both documented and undocumented - born in Mexico (10.2 million) and U.S. citizens of Mexican descent (first- and second-generation, and longer). It is interesting to see how in the early 1980s, with the introduction of neoliberal policies, Mexican migration begins to expand and, with the 1994 launch of NAFTA, increases even further (see Figure III).

${ }^{4} \mathrm{At}$ least five broad phases can be identified: (i) hiring of migrant workers to build railroads in the United States (late 19th century to 1929); (ii) deportation of migrants and land redistribution in Mexico (1929 to 1941); (iii) Bracero Program (1942 to 1964); (iv) emergence of undocumented migration (1964 to 1986); and (iv) mass exports of labor under neoliberal policies and NAFTA (1987 on). 
Figure III. Population of Mexican-Origin in the US

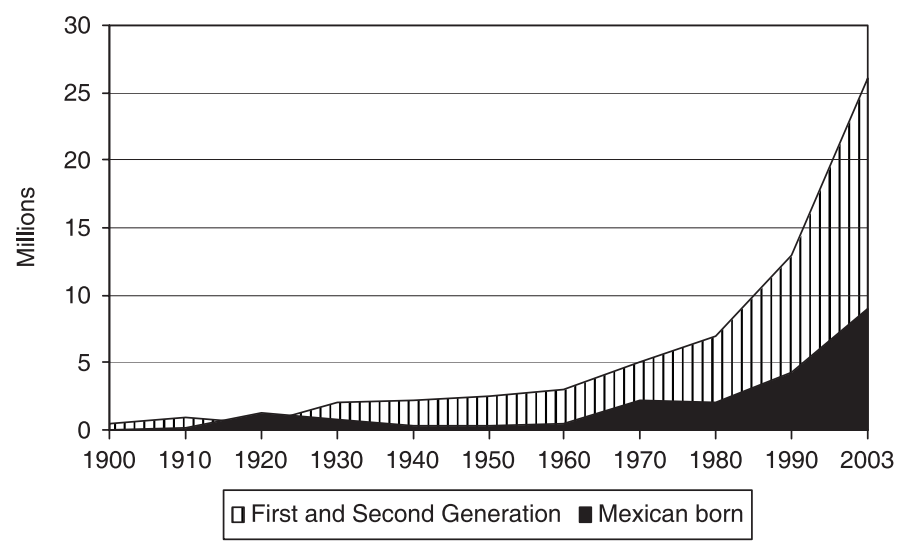

Source: Conapo estimates, based on the Current Population Survey.

Figure IV. Growth of Remittances in Mexico (US\$ millions)

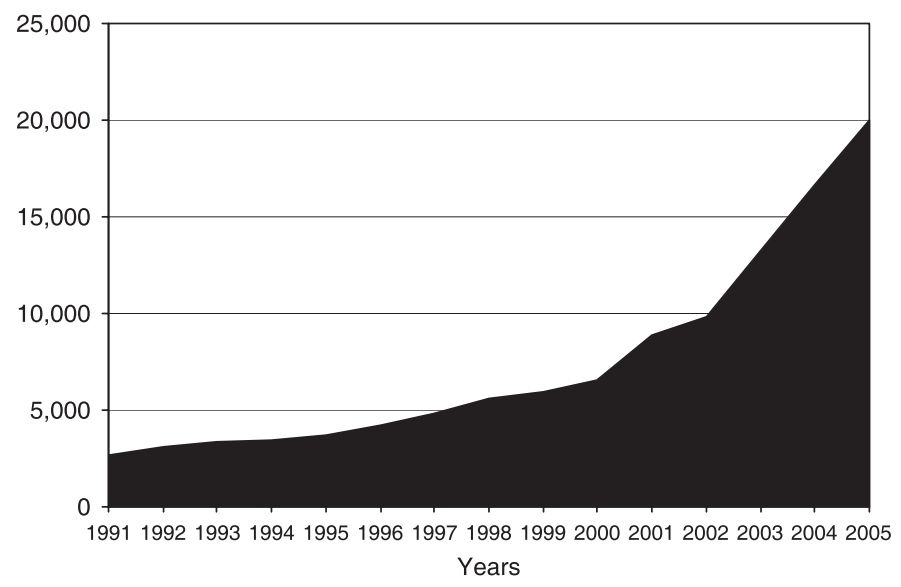

Source: Bank of Mexico.

In line with this dynamic, the country experienced an exponential growth in the flow of remittances (see Figure IV), to the extent that it is now the world's third-largest recipient, its total volume only slightly below that of India and China (World Bank, 2006). In 2005, total remittances received by Mexico amounted to US\$20 billion (Banco de México, 2006). 
In addition to the quantitative increases in the phenomenon, major qualitative transformations are also taking place:

- Practically the whole of Mexico's territory reports international migration: in 2000, $96.2 \%$ of the country's municipalities reported some form of association with it. This territorial expansion has fueled the emergence of new migratory circuits (historic, indigenous-traditional, emerging, etc.) with contrasting dynamics and sets of problems (Zúniga and Leite, 2004). In parallel to this, the population of Mexican-origin residents in the U.S. - although they remain concentrated in a handful of states - has expanded in recent years into most of that country's territory. It should be noted, inter alia, that the migratory circuits are currently expanding into the eastern and north-central parts of the U.S. (Zúñiga and HernándezLeón, 2005), where some of the most dynamic industrial restructuring centers are located (Champlin and Hake, 2006).

- In terms of their schooling, 38.9\% of the population aged 15 years and older born in Mexico and residing in the U.S. has a level of education higher than a basic high-school diploma. This figure rises to $52.4 \%$ if the full spectrum of the population of Mexican origin in the U.S. is taken into consideration. In contrast the average figure for Mexico is $27.8 \%$, which means that, in general terms and in contrast to what is commonly believed, more qualified workers are leaving than remaining in the country. In other words, there is a clear selective trend, in line with the underlying rationale behind international migrations. It should be noted, however, that in comparison to other immigrant groups in the U.S., the Mexican contingent is the one with the lowest average levels of schooling. This circumstance does not attenuate the problem, but rather serves to underscore the serious educational backwardness that still exists in Mexico (OECD, 2005).

- One low-profile form of migration that does not fall in with the stereotypes involves Mexican residents in the U.S. who have university degrees or postgraduate qualifications. That group totals slightly more than 261,000 people born in Mexico, of whom 39,748 have postgraduate qualifications or specializations and 9,961 have doctorates (CPS, 2005). This indicates that the "brain drain" is beginning to emerge as a major problem.

- All of these changes have been accompanied by a major transformation within migration patterns: from a pattern of predominantly circular migration it is evolving into one in which established migrants prevail, 
including variants such as greater participation by women and entire families. Although the trend toward settlement is generally the result of the evolution and maturing of migratory flows, it is in this case accompanied by the unilateral closure of the border which, instead of containing the population exodus as was its stated aim, encourages migrant flows to prolong their stays indefinitely because of the difficulties and risks of returning (Massey, Durand, and Malone, 2002).

- The change in migratory patterns and falling birth rates domestically are leading to a growing and worrisome trend of depopulation: between 2000 and 2005, of the country's 2,435 municipalities, 832 (one out of every three) reported a negative rate of population growth (INEGI, 2006).

- Another notable feature of the new dynamism in Mexico-United States migration is the maturation process of migratory social networks and, more particularly, the emergence of a broad and varied array of migrant organizations. This characteristic means that the growing exodus of Mexicans is not a net loss for Mexico and, on the contrary, can lead to the emergence of new social agents who can act, albeit in a limited fashion, as interlocutors for the migrant community in the United States and, simultaneously, contribute their resources and administrative skills to social and public works and, to a lesser extent, to productive investment in small projects in Mexico. All of these point to a level of transnationality that, contrary to the famous theses of Huntington (2004), assists integration in the receiving society and the maintenance of constructive ties with the migrants' places of origin (Portes, 2005).

- Finally, it should be noted that because of the hemispheric dimension adopted by the economic integration policy promoted by the U.S. government, increasingly Mexico has also been forced to serve as a transit country, with all the problems that that entails. In 2004 more than 1.8 million crossings were recorded on Mexico's southern border, of which $22 \%$ were estimated to be by undocumented Central American migrants (Rodríguez and Nájera, 2005).

Ultimately, the purely quantitative and qualitative description of the rising flow of Mexican migrants is clearly incomplete if it fails to highlight the role played by Mexican labor in the U.S. economy, an issue that is most often omitted from political debates about immigration. For the receiving country, immigrants increase the volume and flexibility of the labor supply in certain segments of the job market, which translates into lower labor costs and, consequently, benefits for capital. In addition, immigrants help dynamize the 
domestic market, sustain the social security system (Anderson, 2005), and increase the volume of financial, transportation, and communications operations. Moreover, their contribution is far from negligible since, according to estimates by Ruiz-Durán (2004), in 2003 Mexican migrant workers contributed $8.0 \%$ of U.S. GDP, which also suggests the potential that is being lost for the growth of Mexico.

Since the 1980s, the U.S. labor market has been undergoing a process of restructuring and precarization, euphemistically referred to as "flexible specialization." In broad terms, Mexican immigrants participate in two segments of that market:

1. A vast sector of increasingly precarious jobs against a backdrop of wide-ranging social exclusion as a forerunner to productive restructuring (e.g., agriculture, domestic service, and cleaning jobs).

2. A sizeable emerging precarized occupational segment associated with productive restructuring in different areas: cutting-edge sectors, production of wage goods, and mature industries undergoing rescues.

In most cases, these jobs require low qualification levels, pay low wages, offer limited or no fringe benefits, are unstable, and the associated labor relations are unilateral, informal (or authoritarian), risky, and subject to extralegal abuse by employers (wages below the legal minimum, arbitrary dismissals, irregularities in overtime payments). Perhaps appropriately, Mexican immigrants have been called disposable workers (Levine, 2001). In general terms, Mexican workers earn lower wages than the native population and other immigrants (see Figure V).

One feature that contributes to the extreme precarization of the Mexican immigrant workforce is its undocumented status. According to figures from the Current Population Survey, in 2002 there were 5.3 million undocumented Mexicans in the United States (Passel, 2004), equal to approximately 60\% of the Mexican-born immigrant population.

Noteworthy in the occupational distribution of immigrants is their growing presence in construction, manufacturing, services, and commerce, particularly in degraded sectors, also known as the backyard of those industries undergoing restructuring: sweatshops, subcontracting, domestic work, day labor, etc. (see Figure VI).

In the manufacturing sector, most are concentrated in the basic metals, metallic products, and machinery and equipment industries $(502,000)$, and in the food and clothing industries $(437,000)$. The first group are mature 
Figure V. Main Occupations of Mexican Immigrants in the U.S., 2004 (percentages)

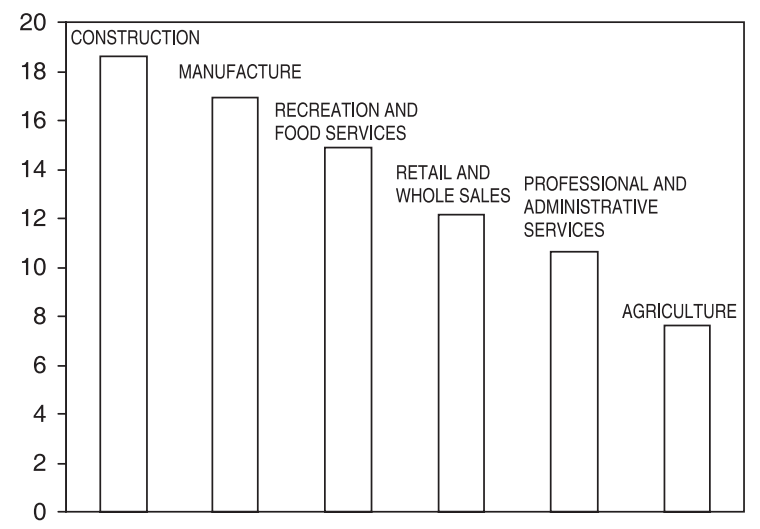

Source: Own estimates, based on the Current Population Survey. U.S. Bureau of the Census.

Figure VI. USA: Average Annual Earnings by Country and Region of Birth, 2003 (US\$)

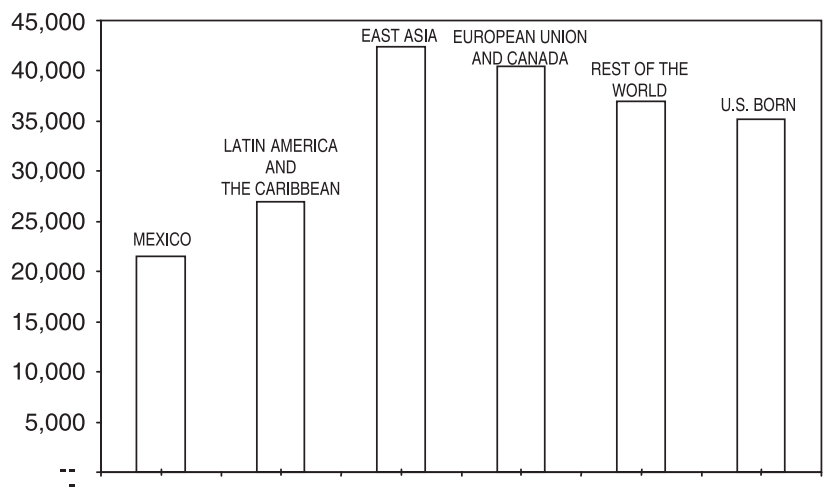

Source: Conapo estimates, based on the Current Population Survey.

industries that are using migrant labor as a rescue strategy (Champlin and Hake, 2006), and the second group involve wage goods for the generalized cheapening of the workforce.

Another angle for viewing the role of Mexican workers in U.S. industrial restructuring is the following: between 1996 and 2004 the participation of U.S. manufacturing workers fell by $18 \%$, while that of Mexican immigrants grew by $13.9 \%$ (Delgado and Cypher, 2005). What is taking place is the 
replacement of the (generally native) better-paid, more experienced, and unionized workforce with Mexican workers, with the clear purpose of reducing operating costs in order to increase profits and global competitiveness.

The importance of Mexican labor in the USA's industrial restructuring process can be appreciated more clearly by considering the expanded U.S. manufacturing system: in other words, manufacturing plants physically located in the United States, and those parts of the productive process that operate in Mexico through maquilas and disguised maquilas. In this case, the employed workforce totals 15.9 million - 14.2 million in the United States and 1.7 million in Mexico - of whom 2.9 million (18\% of the total) are Mexican workers. This means that one out of every five workers in the extended U.S. manufacturing system is a Mexican (Delgado and Cypher, 2005).

Even though the relative participation of Mexican immigrants in agriculture is low in comparison with other occupations (5.9\%), within that sector they represent, by far, the majority group: three of every four agricultural workers were born in Mexico. Most (53\%) are undocumented, with indigenous people and women accounting for a large proportion. This is related to the differentiated processes of social inclusion among immigrants, in accordance with the migratory circuits in which they participate: from transnational vulnerability and exclusion (Besserer, 2002), particularly among immigrants of indigenous descent, to a certain level of upward assimilation, found in the historic circuit.

It should also be noted that the transnationalization and precarization of labor obey structural factors that catalyze mass migration: (1) internationalization of production, which breaks down and complements intra- and interindustrial productive chains; and (2) complementary demographic structures: higher relative aging in the U.S., and Mexico's late "demographic transition." Under that perspective, the productive restructuring process is complemented, but not determined by, changes in demographic patterns.

\section{PARADOXES OF ECONOMIC INTEGRATION AND LABOR MIGRATION}

The labor export-led model gives rise to two paradoxes that are symptomatic of the unsustainability of the current regional integration under way between the Mexican and U.S. economies:

First paradox: The economic integration promoted by the North American Free Trade Agreement, instead of favoring the convergence of Mexico and the United States in terms of development, promotes the deepening of the asymmetries that exist between the two countries. 
The economic integration of Mexico and the United States has contributed to the stagnation of the Mexican economy since its mainstay, the labor exportled model, generates no productive chains and, on the contrary, unleashes a process of deaccumulation caused by the transfer of surpluses abroad. Moreover, the macroeconomic policies on which that model is based tend toward the dismantling of the productive apparatus that targets the national domestic market (Calva, 2005); all of this leads to (i) the precarization and flexibilization of the already shaky formal employment sector, (ii) the proliferation of informal employment, and (iii) increased flows of Mexican migrants headed for the United States.

As a corollary, the labor export-led model helps dynamize the U.S. economy, broadening and deepening the socioeconomic asymmetries between Mexico and the United States. One way of highlighting this trend is to compare the evolution of per capita GDP in the two countries. Instead of there being convergence in this conventional indicator of development, the gap between the two is growing: whereas in 1994 per capita GDP in the U.S. was 2.6 times that of Mexico, by 2004 the ratio had increased to 2.9. Similarly, average manufacturing wages in dollars per hour in the U.S. were 5.7 times higher than those reported in Mexico in 1994, and 6.8 higher in 2004. Paradoxically, while the gap between the wages earned in Mexico and the United States is increasing, the same is not true of their productivity levels: on the contrary, the difference has been falling and, in some cases, Mexican productivity is higher in some productive sectors, particularly those that are a part of the labor export-led model. Other useful development indicators also point to this trend, such as indicators of levels of education and of investment in research and development (see Table 2).

Objectively, rather than a free-trade agreement, NAFTA can be described as a component in the industrial restructuring process of the United States in that it is a mechanism for the provision of cheap labor. That is why, instead of allowing the free movement of workers, it seeks to take advantage of the labor cost advantages offered by the segmentation and differentiation of the binational labor market. That explains why, with the passage of time and in contrast to the promises made by the agreement's proponents, the wage gap between Mexico and the United States has been widening instead of diminishing (see Figure VII).

Second paradox: Instead of creating job opportunities in Mexico, economic integration has become the driving force behind the direct exportation of the workforce and has heightened socioeconomic dependency on remittances. 
TABLE 2

Asymmetries between Mexico and the United States, 1994-2004

\begin{tabular}{|c|c|c|c|c|}
\hline \multirow[b]{2}{*}{ Asymmetry } & \multicolumn{2}{|c|}{ Mexico } & \multicolumn{2}{|c|}{ United States } \\
\hline & 1994 & 2004 & 1994 & 2004 \\
\hline Population (thousands) & 88,402 & 104,000 & 263,126 & 293,655 \\
\hline Rate of Population Growth & $3.2^{\mathrm{a}}$ & 1.3 & $1.2^{\mathrm{a}}$ & 1.0 \\
\hline Per Capita GDP in Current Dollars & 7,332 & 10,059 & 19,304 & 29,673 \\
\hline Underemployment (\% of the EAP) & 43.7 & 37 & 8.8 & 7.6 \\
\hline Research and Development Spending (\% of GDP) & 0.29 & $0.43^{\mathrm{b}}$ & 2.42 & $2.68^{\mathrm{b}}$ \\
\hline Population with University Studies & & & & \\
\hline (\% of population aged from 25 to 64 ) & $11.9^{\mathrm{a}}$ & $15.4^{\mathrm{b}}$ & $33.3^{\mathrm{a}}$ & $38.4^{\mathrm{b}}$ \\
\hline Manufacturing Wages (dollars per man-hour) & 2.1 & 2.5 & 12 & 16.2 \\
\hline
\end{tabular}

Figure VII. Nominal Hourly Manufacturing Wages

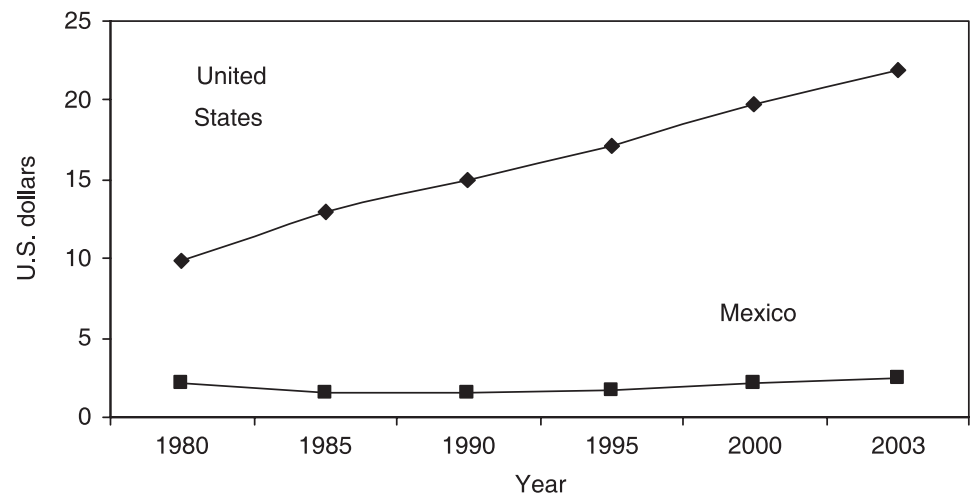

Source: Alianza Jus Semper (2005).

NAFTA has undeniably played a role as a catalyst of migratory flows and not as a catalyst of international cooperation for development, as promised by the treaty text. The Mexico-United States migratory system has spawned a binational labor market that enables the United States to supply itself with major volumes of Mexican workers to cover its needs and labor demands. Since NAFTA came into force, the migrant factory has exported almost 4 million Mexicans to the United States and, by the end of the Fox administration, it is estimated that the figure will have surpassed 7 million (Rodríguez, 2005). The privileged mechanism of this buoyant industry is the creation of a reserve army of workers, at the disposal of the U.S. economy, the training costs of which are mostly borne by Mexican society. In the United States there is a system of 
Figure VIII. Mexico: Importance of Remittances to the Balance of Trade

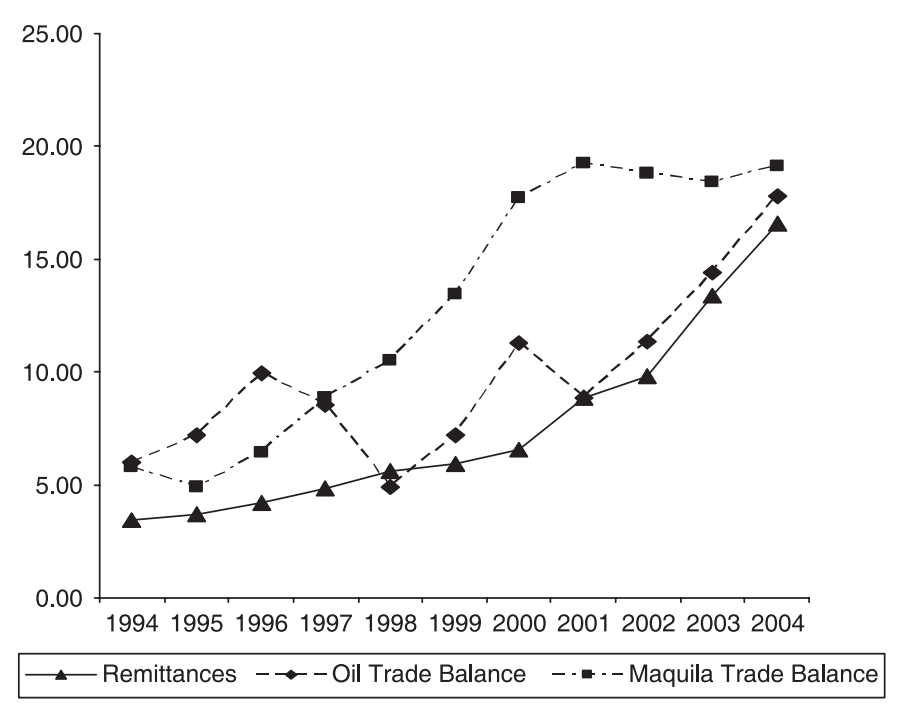

Source: Bank of Mexico.

worker exploitation in place, based on structurally imposed labor flexibility that derives much of its strength on the back of migrant workers who, in most cases, are undocumented.

In parallel to the expansion of migratory flows, there has been a large relative increase in the volume of remittances received by Mexico. At the macro level, remittances are the source of foreign exchange and the mainstay of the balance of trade, together with oil and the maquiladora sector, although the dynamism of the oil industry is unlikely to be maintained and the maquiladora business has stagnated (see Figure VIII). During the period that neoliberal policies have been in force, official figures indicate that remittance receipts have increased 30-fold. In 2005, Banco de México (2006) recorded around 58.7 million transfers, worth an average of US\$341 each, for a total of $\$ 20$ billion.

In certain migrant origin points, at the microsocial level, collective remittances serve to supplement public spending on social infrastructure - e.g., the Three-For-One Program (Tres por Uno) - and, most particularly, family or wage remittances make a substantial contribution to the subsistence expenses of millions of Mexican households. In both cases poverty and marginalization are alleviated, and the state is partially released from its obligation of participating in social development tasks. Migration thus acts as a kind of invaluable 
escape valve (and a safety valve) in light of the economy's reduced structural capacity to expand formal, quality employment.

In those circumstances, it can therefore be claimed that migration operates - while not setting out to do so, and while not on the migrants' agenda - as a crucial source of support for the neoliberal structure, investing it with a veneer of "stability" and, paradoxically, a "human face." At the macro level, remittances serve to prolong the life of a development model that is already showing signs of unsustainability and, at the micro level, they serve to palliate poverty and marginalization, in that they imply transfers of resources without solid ties to savings, improved productive capacity, or economic growth.

The increased importance of remittances to the Mexican economy has led international agencies and the Mexican government to suggest, without addressing the bases of the labor export-led model, that remittances are a sine qua non resource for promoting development. This policy gives shape to a crude version of the labor export-led model: the so-called remittances-based development model (Delgado and Márquez, 2006). However, in addition to distorting the very notion of development, this policy hides the root causes of migration behind the mirage of a fictitious and unsustainable economy created by growing dependence on remittances.

\section{CONCLUSION}

This paper offers a new theoretical approach to the current process of economic integration between Mexico and the United States and to the role played in that context by labor migration in the pursuit of U.S. productive restructuring. The central focus of the analysis is Mexico's labor export-led model, based on two axes: (a) indirect exports through maquilas and disguised maquilas, and (b) direct exports through labor migration. This approach casts light on four aspects of the phenomenon that are particularly revealing of its limitations and contradictions:

1. The growth of Mexican exports under NAFTA, instead of being based on a process of industrialization, has as its touchstone the exportation of cheap Mexican labor. That represents a clear step backward in the evolution of the country's export platform, in that cheap labor is offered as the main static comparative advantage.

2. The indirect exporting of labor through maquilas and disguised maquilas generates practically no upstream or downstream links with the rest of Mexico's productive apparatus. On the contrary, its modus operandi is 
based on low levels of domestic components and on labor precarization and flexibilization. Instead of triggering a vigorous process of accumulation, in reality what ensues is "deaccumulation," in conjunction with the contraction and precarization of the labor market in Mexico, leaving in its wake a meager amount of wage earnings.

3. In this model, Mexican migration is gradually turning into the touchstone. On the one hand, it fuels massive growth in the flows of migrants headed for the United States, to the extent that it is causing a growing and worrisome depopulation in one out of every three Mexican municipalities, with the resultant weakening of its "demographic bonus." On the other, it generates critical socioeconomic dependency on remittances in Mexico which, in practice, means that the labor export-led model evolves into a remittance-based development model.

4. For the U.S. economy, Mexican labor has played a central role in the current process of productive restructuring, aimed at lowering labor costs, both in leading-edge sectors and in the rescue of mature industries, and at the production of wage goods.

Taken as a whole, the case of Mexican migration illustrates the negative consequences and unsustainability of asymmetrical economic integration in conjunction with the internationalization of production and the precarization of crossborder labor markets driven by the U.S. government and U.S. multinational corporations. Seen in that way, the problems of migration cannot be reduced to a simple security issue; instead, they underscore the need to develop new forms of regional integration that will serve to reduce international asymmetries and promote an alternative model for development in Mexico. This situation cannot be ignored within the current political debate in the United States regarding the adoption of a migration policy, or within the design of an international agenda for migration and development.

\section{REFERENCES}

Anderson, S.

2005 The Contribution of Legal Immigration to the Social Security System. Washington DC: National Immigration Forum. <http://www. immigrationforum.org/PrintFriendly.aspx?tabid=146>.

Banco de México

2006 Informe Anual 2005. México: Banco de México.

Baumann, R. et al.

2002 Los Procesos de Integración de los Países de América Latina y el Caribe 2000-2001: Avances, Retrocesos y Temas Pendientes. Santiago: Cepal. 
Besserer, F.

2002 Topografias Transnacionales. Una Geografia para el Estudio de la vida Transnacional. México: Plaza y Valdés.

Cadena, G.

2005 “Manufactura, en la ruta de la 'Desindustrialización'.” El Financiero (16 de agosto:13). Calva, J. L.

2005 "México: La Estrategia Macroeconómica 2001-2006. Promesas, Resultados y Perspectivas." Problemas del desarrollo 36(143):59-87.

Capdevielle, $M$.

2005 "Procesos de Producción Global: ‘alternativa para el Desarrollo Mexicano?" Comercio exterior 55(7):561-573.

Champlin, D., and E. Hake

2006 "Immigration as Industrial Strategy in American Meatpacking." Review of Political Economy 18(1):49-70.

Conapo

2004 Migración internacional. México: Conapo. <http://www.conapo.gob.mx>.

CPS

2005 Current Population Survey. Washington DC: U.S. Census Bureau. <http://www.bls.census.gov>.

De la Garza, E.

2004 Modelos de Producción en el Sector Maquilador: Tecnología, Organización del Trabajo y Relaciones Laborales. Paper presented at the IX Foro de Investigación: Congreso Internacional de Contaduría, Administración e Informática, UNAM, México October 27.

Delgado-Wise, R., and J. Cypher

2005 The Strategic Role of Labor in Mexico's Subordinated Integration into the US Production System under NAFTA. Documento de trabajo 12/11/2005, Doctorado en Estudios del Desarrollo-UAZ. [Working paper 12/11/2005, Doctorate in Studies of the Autonomous University of Zacatecas] , and H. Márquez

2005 "Migración, políticas públicas y desarrollo. Reflexiones en torno al caso de México." Paper presented at Seminario Problemas y Desafíos de la Migración y el Desarrollo en América, Red Internacional de Migración y Desarrollo, Cuernavaca. April 7-9.

2006 ¿Las remesas como soporte del desarrollo? Paradojas del papel de la fuerza de trabajo mexicana en la integración económica de México a Estados Unidos. Documento de trabajo, Doctorado en Estudios del Desarrollo-UAZ. [Working paper 09/03/2006, Doctorate in Studies of the Autonomous University of Zacatecas]

Durán, J., and V. Ventura-Dias

2003 Comercio Intrafirma: Concepto, Alcance y Magnitud. Santiago: Cepal.

Durand, J., and D. Massey

2003 Clandestinos. Migración México-Estados Unidos en los albores del siglo XXI. México: Miguel Ángel Porrúa/Universidad Autónoma de Zacatecas.

Dussel, E.

2006 "La Liberalización comercial en México: ¿ quién se ha beneficiado?" In México en Transición. Ed. G. Otero. México: Miguel Ángel Porrúa/UAZ.

2003 “Ser o no ser Maquila, ¿ es ésa la Pregunta?” Comercio Exterior 53(4):328-336. 
, L. Galindo, and E. Loría

2003 Condiciones y Efectos de la Inversión Extranjera Directa y del Proceso de Integración Regional en México Durante los años Noventa: Una Perspectiva Macroeconómica. Buenos Aires: BID.

ECLAC

1994 El Regionalismo Abierto en América Latina y el Carbie. Santiago: Cepal.

Gereffi, G.

2001 "Las Cadenas Productivas como marco Analítico para la Globalización." Problemas del Desarrollo 32(125):9-37.

Howard, G.

2005 "El Papel del Trabajo: México, Empleos, Pocos y Malos." La Jornada, November 11. <http://www.jornada.unam.mx/2004/08/09/004n1sec.html>.

Huerta, A.

2004 "Estancamiento e Incertidumbre de la Economía Nacional." Economía informa (322):5-14.

Huntington, $S$.

2004 ¿Qué somos? Los Desafíos a la Identidad Nacional Estadounidense. Barcelona: Paidós.

INEGI

2006 Conteo de Población y Vivienda. México: Inegi.

Levine, E.

2001 Los Nuevos Pobres en Estados Unidos: Los Hispanos. México: Miguel Ángel Porrúa.

Massey, D., J. Durand, and N. Malone

2002 Beyond Smoke and Mirrors. Mexican Immigration in an Era of Economic Integration. New York: Russell Sage Foundation.

OECD

2005 "La Emigración de Mexicanos a Estados Unidos." Comercio Exterior 55(2):148-164.

Passel, J.

2004 “Mexican Immigration to the US: The Latest Estimates." Washington DC: Migration Policy Institute. <http://www.migrationinformation. org/feature/display.cfm?ID=208>.

Portes, A.

2005 "Convergencias Teóricas y Evidencias Empíricas en el Estudio del Transnacionalismo de los Inmigrantes." Migración y Desarrollo 4:2-19.

Rodríguez, E., and J. Nájera

2005 La Migración de Tránsito Hacia Estados Unidos por la Frontera sur de México. México: INM/CEM.

Rodríguez, $\mathrm{H}$.

2005 "Tendencias recientes de la migración de mexicanos a Estados Unidos." Paper presented at Segunda Conferencia Internacional sobre la relación Estado-Diáspora, México. October 3-5.

Ruiz-Durán, C.

2004 Integración de los Mercados Laborales en América del Norte. México: Informe de investigación. <http://www.ietrabajo.org.mx>.

Russel, J.

2006 Después del quinto sol. Clase y raza en Norteamérica. México: Miguel Ángel Porrúa.

Tello, C.

1996 “La Economía Mexicana: Hacia el Tercer Milenio.” Nexos 223:47-55. 
United Nations Population Division

2006 World Population Prospects: The 2004 Revision and World Urbanization Prospects: The 2003 Revision. New York: United Nations Population Division. <http://esa.un.org/unpp>.

World Bank

2006 Global Economic Prospects. Economic Implications of Remittances and Migration 2006. Washington DC: World Bank.

2005 World Development Indicators Database. Washington DC: World Bank. <http:// devdata.worldbank.org/data-query/>.

Zúñiga, E., and P. Leite

2004 "Los procesos contemporáneos de la migración México-Estados Unidos: Una perspectiva regional y municipal." Paper presented at the Seminario migración México-Estados Unidos: Implicaciones y retos para ambos países organizado por Conapo. Conapo, Mexico. November 30-December 1.

Zúñiga, V., and R. Hernández-León, ed.

2005 New Destinations: Mexican Immigration in the United States. New York: Russell Sage Foundation. 